УДК 343.131(477)

DOI https://doi.org/10.32838/1606-3716/2020.4/39

\title{
Мудрак I.B.
}

Національний університет «Одеська юридична академія»

\section{ЩОДО УЧАСТІ У КРИМІНАЛЬНОМУ ПРОВАДЖЕННІ ПРАВОНАСТУПНИКА ПОТЕРПІЛОГО}

Статтю присвячено дослідженню інституту правонаступництва в кримінальному провадженні, зокрема участі в кримінальному прочесі правонаступника потерпілого. Зазначається, щуо чинний КПК Украӥни не містить норми, яка б регламентувала правонаступництво в кримінальному провадженні. Водночас елементи кримінально-процесуального правонаступництва в контексті досліджуваної проблематики можна простежити, аналізуючи ч. 6 ст. 55 КПК України, а також аналізуючи матеріали судової практики. Вказується на те, що інститут правонаступництва де-факто є таким, що реально передбачений кримінальним прочесуальним законом, проте де-юре не закріплений.

Досліджується питання щодо подальшої долі кримінального провадження в разі смерті потерпілого, якщо ним була раніше висловлена згода на підтримання обвинувачення або подана заява про вчинення щодо нього кримінального правопорушення (у провадженні у формі приватного обвинувачення) чи надана письмова згода. Висловлюється думка щзодо включення до переліку учасників кримінального провадження правонаступника потерпілого у випадку смерті останнього, якщо між смертю особи і кримінальним правопорушенням (суспільно небезпечним діянням) відсутній причинно-наслідковий зв'язок.

Аналізується, що інститут правонаступництва привносить у кримінальний процес деякі елементи диспозитивності, й тому волевиявлення особи представляти інтереси потерпілого, реалізуючи його права, має бути, звичайно ж, ураховано, $і$ кримінально-прочесуальна активність такої особи буде впливати на подальший рух кримінального провадження та винесення відповідного процесуального рішення.

Зазначається, що правонаступник потерпілого в кримінальному провадженні - ие учасник кримінального провадження, щео подав заяву про залучення його до провадження та перейняв права і обов'язки потерпілого внаслідок смерті потерпілого/особи, щодо якоі було вчинено кримінальне правопорушення (суспільно небезпечне діяння) або внаслідок перебування такої особи у стані, що унеможливлюе подачу заяви про вчинення щзодо неї кримінального правопорушення, якщяо відповідний стан особи чи ї̈ смерть немає причиннонаслідкового зв 'язку із вчиненим кримінальним правопорушенням, яким може бути близький родич чи член сім'ї потерпілого/особи, щодо якого було вчинено кримінальне правопорушення (суспільно небезпечне діяння).

Ключові слова: кримінальне провадження, потерпілий, правонаступник потерпілого, інститут правонаступництва.

Постановка проблеми. Чинний КПК України не містить норми, яка б регламентувала правонаступництво в кримінальному провадженні. Водночас елементи кримінально-процесуального правонаступництва простежуються як у кримінальному процесуальному законі, так і в судовій практиці, що вказує, зокрема, на необхідність та актуальність дослідження проблематики участі у кримінальному провадженні правонаступника потерпілого.

Аналіз останніх досліджень і публікацій. Важливі питання досліджуваної проблеми розглядалися в багатьох працях учених, таких як О.П. Герасимчук, О.П. Кучинська, В.В. Навроцька, В.Г. Пожар, М.І. Тлепова, С.В. Толокольніков та ін.
Постановка завдання. Метою статті є дослідження інституту правонаступництва в кримінальному провадженні, зокрема, в контексті участі в кримінальному процесі правонаступника потерпілого.

Виклад основного матеріалу дослідження. Щодо визначення самого поняття «правонаступник» зазначимо, що, наприклад, словник української мови вказує на правонаступника як на «особу, якій передано всі права і обов'язки або окремі права іншої особи» [1]. Правонаступництво - перехід прав і обов'язків від одного суб'єкта до іншого; правонаступництво може бути універсальним, частковим або зовсім відсутнім [2]. 
Правонаступництво - це перехід суб'єктивного права (в широкому розумінні - також правового обов'язку) від однієї особи праводавця до іншої (правонаступника) в порядку похідного правонабуття (у відповідних випадках - похідного набуття правого обов'язку) [3, с. 311].

Слід сказати, що інститут правонаступництва відомий цивільному процесу України. Так, відповідно до ст. 55 ЦПК, що регламентує процесуальне правонаступництво, у разі смерті фізичної особи, припинення юридичної особи, заміни кредитора чи боржника у зобов'язанні, а також в інших випадках заміни особи у відносинах, щодо яких виник спір, суд залучає до участі у справі правонаступника відповідної сторони або третьої особи на будь-якій стадії судового процесу. Усі дії, вчинені в цивільному процесі до вступу правонаступника, обов'язкові для нього так само, як вони були обов'язкові для особи, яку він замінив.

Чинний КПК України не містить норми, яка 6 регламентувала правонаступництво в кримінальному провадженні. Водночас елементи кримінально-процесуального правонаступництва можна простежити, наприклад, аналізуючи ч. 6 ст. 55 КПК України: «Якщо внаслідок кримінального правопорушення настала смерть особи або особа перебуває у стані, який унеможливлює подання нею відповідної заяви, положення частини першої - третьої цієї статті поширюються на близьких родичів та членів сім'ї такої особи. Потерпілим визнається одна особа 3 числа близьких родичів чи членів сім'ї, яка подала заяву про залучення іiі до провадження як потерпілого, а за відповідним клопотанням - потерпілими може бути визнано кілька осіб» [4]. Зокрема, п. 27 Постанови ВП ВС вказує на те, що «водночас у частині 6 ст. 55 КПК України передбачено так зване правонаступництво у кримінальному провадженні». Разом із тим згідно з п. 33 Постанови «право на примирення у ст. 46 КК - це особисте право потерпілого. Воно не може бути ніким присвоєне та нікому делеговане. Таке право $є$ природним правом людини, нерозривно пов'язаним 3 нею та похідним від інших прав, зокрема права на життя. Використання права на примирення іншими особами (у тому числі визнаними потерпілими від кримінального правопорушення в кримінальному процесуальному сенсі) $є$ неможливим, оскільки таке право тісно пов'язане з особою, яка безпосередньо постраждала внаслідок учинення щодо неї кримінального правопорушення. Під час примирення лише сам потерпілий може виражати свою волю, а не інші особи, які є його представниками або правонаступниками» [5]. Тому, вважаємо, можна зауважити, що інститут правонаступництва де-факто є таким, що реально передбачений кримінальним процесуальний законом, проте де-юре він не закріплений.

Відмітимо, що Кримінально-процесуальний кодекс Республіки Білорусь [6] та Кримінальнопроцесуальний кодекс Республіки Казахстан [7] містять термін «правонаступник». Так, згідно 3 п. 25 ч. 1 ст. 6 Кримінально-процесуального кодексу Республіки Білорусь «правонаступник особа, якій силою закону чи угоди безпосередньо від іншої особи перейшло встановлене право» [6].

Дискусійним $є$ питання щодо подальшої долі кримінального провадження в разі смерті потерпілого, якщо ним була раніше висловлена згода на підтримання обвинувачення або подана заява про вчинення щодо нього кримінального правопорушення (в провадженні у формі приватного обвинувачення) чи надана письмова згода (загальний порядок кримінального провадження). У даному випадку доречним і необхідним $є$ введення інституту правонаступництва для виконання завдань кримінального процесу. Адже смерть потерпілого не передбачено як підставу для закриття провадження, та й відмова прокурора теж не може бути підставою для закриття провадження, оскільки потерпілий прийняв підтримання обвинувачення самостійно.

Здавалося б, частково відповідь на це питання знаходимо у ч. 6 ст. 55 КПК, де йдеться про те, що якщо внаслідок кримінального правопорушення настала смерть особи або особа перебуває у стані, який унеможливлює подання нею відповідної заяви, положення частин першої - третьої цієї статті поширюються на близьких родичів або членів сім'ї такої особи. Проте тут виникає чимало запитань. А якщо смерть потерпілого настала не як наслідок кримінального правопорушення? А якщо у потерпілого, смерть якого настала під час кримінального провадження після висловлення ним згоди на підтримання обвинувачення/подачі заяви про вчинення щодо нього кримінального правопорушення, немає близьких родичів чи членів сім'ї? Які правові наслідки смерті потерпілого в кримінальному провадженні у формі приватного обвинувачення, що сталася 3 причин, що не залежать від вчинення кримінального правопорушення? У цьому випадку близькі родичі і члени сім'ї не мають можливості набути процесуального статусу потерпілого, оскільки обов'язковим $\epsilon$ причинно-наслідковий зв'язок між злочинним діянням та смертю особи. Водночас для захисту 
особи, права та законні інтереси якої були порушені внаслідок вчинення кримінального правопорушення, кримінальне провадження має обов'язково продовжуватися, оскільки такою процесуальною дією, як подання заяви про кримінальне правопорушення до відповідних органів, потерпілий однозначно висловив своє бажання притягнути винного до кримінальної відповідальності, а це і є завданням кримінального провадження.

Тому слід погодитися 3 пропозицією щодо включення до переліку учасників кримінального провадження правонаступника потерпілого у випадку смерті останнього, якщо між смертю особи і кримінальним правопорушенням (суспільно небезпечним діянням) відсутній причиннонаслідковий зв'язок [8].

Щодо впровадження інституту правонаступництва загиблого потерпілого висловлювався і О.П. Герасимчук, зазначаючи, що саме термін «правонаступники» найбільш точно відображає перехід прав потерпілого до інших осіб (близьких родичів), та вказував на осіб, які можуть бути правонаступниками померлого потерпілого, згрупувавши їх на кілька черг:

- батьки, опікуни (піклувальники), діти (у т. ч. усиновлені), утриманці, інше з подружжя, онуки;

- брати, сестри, дід, баба;

- рідні дядько, тітка;

- особи, які спільно проживали із загиблим однією сім'єю не менш ніж як упродовж останніх п'яти років;

- інші родичі, які виявили бажання представляти інтереси потерпілого в кримінальному судочинстві [9].

На нашу думку, інститут правонаступництва у разі смерті потерпілого в кримінальному провадженні неодмінно має набути законодавчого врегулювання, і відповідні зміни слід вносити до тексту чинного КПК України. I це має значення не тільки для здійснення кримінального провадження у формі приватного обвинувачення, а й для ефективного здійснення кримінального провадження загалом. Про це, зокрема, свідчить і судова практика, оскільки даний термін активно використовується в судових рішеннях у кримінальному провадженні, однак його використання водночас не зовсім узгоджується в розумінні змістовно-процесуального навантаження з відповідними положеннями кримінального процесуального закону, який навіть не визначає поняття правонаступника потерпілого в кримінальному провадженні. Наприклад, в ухвалі Жовтневого районного суду м. Маріуполя Донецької області про призначення судового розгляду від 21.06.2016 року йдеться про те, що «в судовому засіданні ОСОБА_2 заявила про залучення іiі до участі у справі як правонаступника потерпілої ОСОБА 3, оскільки це іiі матір, яка померла 03.04.2016 року...» Суд ухвалив, посилаючись на ч. 6, 7 ст. 55 КПК: «У зв’язку зі смертю потерпілої ОСОБА_3 визнати і1ї доньку ОСОБА_2 потерпілою в рамках кримінального провадження...» [10]. Ч. 6, 7 ст. 55 КПК не згадують про правонаступника потерпілого. Саме тому суд ухвалює визнати особу потерпілою у кримінальному провадженні, не згадуючи зовсім про те, чи внаслідок кримінального правопорушення настала смерть потерпілої ОСОБА_3, чи ні.

Для прикладу, відповідно до ухвали Нововодолазького районного суду Харьковської області від 05.01.2017 року «до початку підготовчого судового засідання ОСОБА_3 надав до суду заяву, відповідно до якої просив визнати його потерпілим по даному кримінальному провадженню. В обгрунтування заявленого клопотання зазначив, що він є рідним сином ОСОБА_4 - потерпілого по даному кримінальному провадженню. Оскільки його батько помер ІНФОРМАЦІЯ_1, просив визнати його потерпілим, додавши при цьому копію свідоцтва про народження та копію свідоцтва про смерть батька. У судовому засіданні прокурор висловив думку про необхідність відмови в задоволенні клопотання, оскільки смерть потерпілого ОСОБА_4 настала не внаслідок злочину. Захисник обвинуваченого, а також сам обвинувачений ОСОБА_2 проти задоволення заяви ОСОБА_3 заперечували, посилаючись на те, що діючим КПК України прямо не передбачено правонаступництво у кримінальному процесі.

Суд дійшов висновку, що положення ст. 55 КПК України застосовується й у випадках, коли смерть потерпілого настала не тільки внаслідок кримінального правопорушення, а й по інших причинах після вчинення злочину, що мали місце вже в процесі кримінального провадження. Оскільки факт смерті потерпілого ОСОБА_4, хоча і не внаслідок кримінального правопорушення, унеможливлює його участь у справі, суд доходить висновку про необхідність визнання ОСОБА_3 потерпілим по даному кримінальному провадженні» [11].

Також зауважимо, що інститут правонаступництва привносить у кримінальний процес деякі елементи диспозитивності, й тому волевиявлення особи представляти інтереси потерпілого, реалізуючи його права, має бути, звичайно ж, ураховано, і кримінально-процесуальна активність 
такої особи буде впливати на подальший рух кримінального провадження та винесення відповідного процесуального рішення. А отже, має бути врегульовано, крім іншого, процедуру відмови правонаступника потерпілого від участі в кримінальному провадженні в разі смерті останнього.

Гарантією реалізації права близьких осіб на правонаступництво мав би бути обов'язок особи, яка провадить досудове розслідування справи, чи судді повідомити їх про це право, роз'яснити це право та зафіксувати таку процесуальну дію у відповідному протоколі.

Погоджуємося 3 думкою про те, що бажання правонаступника щодо вступу в процес може виявлятися або в поданні ним (його представником) відповідної заяви до органу, що веде кримінальний процес, або шляхом усної заяви, яка має бути занесена до відповідного протоколу [12].

У зв'язку з вищенаведеним, на нашу думку, слід внести, зокрема, такі зміни до окремих положень чинного КПК України:

до ч. 1 ст. 3 КПК (щодо визначення терміна «правонаступник потерпілого»), зокрема до п. 25, 26 ч. 1 ст. 3 КПК (щодо визначення правонаступника потерпілого учасником кримінального провадження та учасником судового провадження);

ст. 59-1 КПК «Правонаступник потерпілого» (окремою статтею КПК визначити правонаступника потерпілого як учасника кримінального провадження);

п. 7 ч. 1 ст. 284 КПК (щодо закриття кримінального провадження потерпілим, а у випадках, передбачених цим Кодексом, його представником або правонаступником у разі їхньої відмови від обвинувачення у кримінальному провадженні у формі приватного обвинувачення);

п. 7-1 ч. 1 ст. 284 КПК (окремо врегулювати питання закриття кримінального провадження в разі відмови правонаступника потерпілого брати участь у кримінальному провадженні); крім того, вважаємо, в разі смерті потерпілого, якщо його смерть не має причинно-наслідкового зв'язку із вчиненим щодо нього кримінальним правопорушенням, близькі родичі, члени сім’ї потерпілого мають бути проінформовані про їхнє право бути залученими до кримінального провадження як правонаступники; ч. 6 ст. 55 КПК (доповнити відповідну частину статті, окремо врегулювавши питання щодо участі правонаступника потерпілого в кримінальному провадженні в разі смерті потерпілого, що не $\epsilon$ наслідком кримінального правопорушення);

п. 7 ч. 1 ст. 393 КПК (щодо права правонаступника потерпілого на апеляційне оскарження);

п. 7 ч. 1 ст. 425 КПК (щодо права правонаступника потерпілого на касаційне оскарження);

ч. 1 ст. 477 КПК (щодо заяви правонаступника потерпілого як підстави до початку кримінального провадження у формі приватного обвинувачення);

ст. 478 КПК (щодо права правонаступника потерпілого подати до слідчого, прокурора, іншої службової особи органу, уповноваженого на початок досудового розслідування, заяву про вчинення кримінального правопорушення протягом строку давності притягнення до кримінальної відповідальності за вчинення певного кримінального правопорушення).

Висновки. Процесуальне правонаступництво в кримінальному судочинстві - особливий випадок заміни сторони іншою особою (правонаступником) в разі іiі вибуття з процесу та у випадку переходу до неї матеріальних прав та обов'язків у встановлюваних судом правовідносинах. Правонаступництво на боці цивільного позивача може відбуватися тільки в разі згоди правонаступника матеріальних прав та обов'язків на цю заміну і на вступ у процес [12].

Підсумовуючи, вважаємо, що правонаступник потерпілого в кримінальному провадженні - це учасник кримінального провадження, що подав заяву про залучення його до провадження та перейняв права і обов'язки потерпілого внаслідок смерті потерпілого/особи, щодо якої було вчинено кримінальне правопорушення (суспільно небезпечне діяння), або внаслідок перебування такої особи у стані, що унеможливлює подачу заяви про вчинення щодо неї кримінального правопорушення, якщо відповідний стан особи чи ії смерть не має причинно-наслідкового зв'язку із вчиненим кримінальним правопорушенням, яким може бути близький родич або член сім'ї потерпілого/ особи, щодо якої було вчинено кримінальне правопорушення (суспільно небезпечне діяння).

\section{Список літератури:}

1. Словник української мови : в 11 томах. 1976. Том 7, 1976. С. 508. URL: http://sum.in.ua/ s/pravonastupnyk

2. Словничок юридичних термінів : навч. посіб. Київ : МАУП, 2003. URL: https:/moskalik.at.ua/pravo/ PR4_01.pdf

3. Черепахин Б.Б. Правопреемство по советскому гражданскому праву. Труды по гражданскому праву. Москва : Статут, 2001. 479 с. 
4. Кримінальний процесуальний кодекс України від 13.04.2012 p. URL: https://zakon.rada.gov.ua/laws/ show/4651-17\#Text

5. Постанова Великої Палати Верховного Суду від 16.01.2019 p. URL: https://zib.com.ua/ua/136645-vs_ smert_poterpilogo_unemozhlivlyue_primirennya_storin.html

6. Кримінально-процесуальний кодекс Республіки Білорусь від 16.07.1999 p. URL: https://etalonline.by/ document/?regnum $=\mathrm{hk} 9900295$

7. Кримінально-процесуальний кодекс Республіки Казахстан від 04.07.2014 p. URL: https://online.zakon.kz/document/?doc_id $=31575852 \#$ pos $=3 ;-88$

8. Тлепова М.І. Процесуальне становище потерпілого під час досудового розслідування : автореф. дис. ... канд. юрид. наук : 12.00.09. Харків, 2016. 23 с. URL: http://nauka.nlu.edu.ua/download/diss/ Tlepova/a_Tlepova.pdf

9. Герасимчук О.П. Правонаступництво у кримінальному процесі у випадку смерті потерпілого. Адвокат. URL: http://naub.org.ua/?p=764

10. УхвалаЖовтневогорайонного судум. Маріуполя від 21.06.2016p. URL:https://verdictum.ligazakon.net/ document $/ 58414639$

11. Ухвала Нововодолазького районного суду Харьковської області від 05.01.2017 p. URL: https://verdictum.ligazakon.net/document/63925025

12. Навроцька В.В. Процесуальне правонаступництво при розгляді цивільного позову у кримінальній справі. URL: http://www.lvduvs.edu.ua/documents_pdf/visnyky/nvsy/01_2010/nvvuks.pdf

\section{Mudrak I.V. REGARDING TO PARTICIPATION IN CRIMINAL PROCEEDINGS OF THE SUCCESSOR OF THE VICTIM}

The article is devoted to the study of the institution of succession in criminal proceedings, in particular, the participation in the criminal process of the victim's successor. It is noted that the current CPC of Ukraine does not contain a rule that would regulate succession in criminal proceedings. At the same time, the elements of criminal procedural succession in the context of the studied issues can be traced by analyzing Part 6 of Art. 55 of the CPC of Ukraine, as well as analyzing the materials of judicial practice. It is pointed out that the institution of legal succession is de facto such that it is actually provided by the criminal procedure law, but de jure it is not fixed.

The question of the further fate of the criminal proceedings in case of death of the victim is investigated, if he has previously agreed to support the accusation or filed a statement of a criminal offense against him (in the form of private prosecution) / written consent. The opinion is expressed on the inclusion in the list of participants in criminal proceedings of the successor of the victim in case of death of the latter, if there is no causal link between the death of a person and a criminal offense (socially dangerous act).

It is analyzed that the institution of succession introduces into the criminal process some elements of dispositiveness and therefore the will of a person to represent the interests of the victim, exercising his rights, should, of course, be taken into account, and criminal procedural activity of such person decision.

It is noted that the successor of the victim in criminal proceedings is a participant in criminal proceedings who filed an application to involve him in the proceedings and took over the rights and obligations of the victim as a result of death of the victim / person against whom a criminal offense was committed. such a person in a condition that makes it impossible to file an application for the commission of a criminal offense against him, if the relevant condition of the person or his death has no causal connection with the committed criminal offense.

Key words: criminal proceedings, victim, legal successor of the victim, institute of legal succession. 